\title{
Four Classes of Salicylate-Induced Tobacco Genes
}

\author{
Diana M. Horvath, Dorothy J. Huang, and Nam-Hai Chua \\ Laboratory of Plant Molecular Biology, The Rockefeller University, 1230 York Avenue, New York, NY 10021 \\ U.S.A. \\ Accepted 6 June 1998.
}

\begin{abstract}
We have identified and characterized fragments of 15 salicylic acid (SA) early response genes. The kinetics of induction and response to cycloheximide (CHX) treatment allowed classification of genes into four groups. Classes I-III are characterized by immediate-early responses, showing increased accumulation of mRNA within $30 \mathrm{~min}$ of $\mathrm{SA}$ treatment. Moreover, $\mathrm{CHX}$ did not block induction of these genes, indicating that latent cellular factors mediate the $\mathrm{SA}$ response. Class IV genes were induced more slowly, but still within 2 to $3 \mathrm{~h}$ of SA treatment, and required protein synthesis for expression. Although identified in this study as SA-responsive genes, several could also be induced by other compounds. Two genes were characterized in more detail, including isolation of cDNA sequences and additional analysis of gene expression. Sequence analysis revealed that the class I gene, $\mathrm{Cl}$-1, is the previously identified ethylene response element binding protein 1 (EREBP1), an ethylene-induced transcription factor for basic pathogenesis-related (PR) genes, whereas the class III gene, $G 8-1$, is a novel sequence. $G 8-1$ was found to be strongly induced only by $\mathrm{SA}$ and its active analogs and was exquisitely sensitive to low $\mathrm{SA}$ concentrations. These and other genes were found to be activated at early times following tobacco mosaic virus infection of resistant tobacco genotypes.
\end{abstract}

Additional keywords: auxin, differential display, hydrogen peroxide.

Although many aspects of genetic plant disease resistance have been characterized, little is known about the role of salicylic acid (SA) in this process. Research efforts, particularly over the past 8 years, have demonstrated the following: (i) SA levels increase during a hypersensitive response (HR) to a pathogen (Malamy et al. 1990); (ii) both SA accumulation and HR lesion formation following tobacco mosaic virus (TMV)

Corresponding author: Diana M. Horvath; Telephone: 1-212-661-2255; Fax: 1-212-972-6265; E-mail: dhorvath@atp-lp.com

Current address of Diana M. Horvath: Agricultural Technology Partners, Suite 3410, 60 East 42nd St., New York, NY 10165 U.S.A.

Current address of Dorothy J. Huang: University of Pennsylvania, Philadelphia, U.S.A.

Nucleotide and/or amino acid sequence data are to be found at GenBank at the following accession nos.: C14-1b, AF057370; C16-1, AF057371; C18-1 (cDNA), AF057373; C2-1, AF057375; C6-2, AF057377; G2-1, AF057376; G3-1, AF057372; G3-2, AF057374; G8-1 (cDNA), AF057379; G8-5, AF057378. infection are blocked at high temperatures; and (iii) engineering of plants with certain transgenes, such as bacteria opsin, cholera toxin, or invertase, as well as certain Arabidopsis thaliana mutants, produces elevated levels of SA, constitutive expression of pathogenesis-related (PR) genes, enhanced disease resistance, and, in some cases, HR lesion formation in the absence of pathogen (cf. Durner et al. 1997). Conversely, plants that are deficient in the ability to accumulate or respond to SA are impaired in disease resistance responses (e.g., NahG transgenics and nprl/niml/ sail, reviewed in Durner et al. 1997). Other data indicate that SA also functions to potentiate defense responses by enhancing defense gene induction, the production of active oxygen species, and cell death (cf. Draper 1997).

Some progress has been made in identifying signal transduction components that mediate the SA response. An SA binding protein identified as catalase was initially thought to convert the SA signal into increases in hydrogen peroxide $\left(\mathrm{H}_{2} \mathrm{O}_{2}\right)$, by inhibition of catalase function (Chen et al. 1993). Because $\mathrm{H}_{2} \mathrm{O}_{2}$ treatment was found to induce PR gene expression in tobacco, Klessig and co-workers proposed that $\mathrm{H}_{2} \mathrm{O}_{2}$ was a downstream signal in the pathway to induced defense responses. Subsequently, however, it has been demonstrated that $\mathrm{H}_{2} \mathrm{O}_{2}$ induction of PR genes is dependent on SA accumulation (Bi et al. 1995; Neuenschwander et al. 1995). Recently, a second SA binding protein, SABP2, has been characterized with a 150-fold higher binding affinity than catalase (Du and Klessig 1997). Several features of SABP2 are consistent with this protein functioning as an SA receptor. Jupin and Chua (1996) have identified a tobacco DNA binding activity, known as SARP, that consists of a TGA1a-related, bZIP-family transcription factor. In the absence of SA, SARP exists as an inactive complex, but treatment with SA for $1 \mathrm{~h}$ produced binding to the SA-inducible as-1 element of the cauliflower mosaic virus $35 \mathrm{~S}$ promoter. SARP could be released from its inhibitory component, SAI, by treatment of control extracts with dissociating agents. Because phosphatase treatment of SA-induced extracts blocked DNA binding activity, it is likely that the natural signal transduction pathway to release SARP following SA treatment involves phosphorylation. Similar results have been reported by Strange et al. (1997). One kinase with features consistent with this response is the SIP kinase, a MAP kinase family member that is rapidly and transiently induced following treatment of cultured tobacco cells with SA. Kinase activity increased from background to peak activity within $5 \mathrm{~min}$ and diminished by $45 \mathrm{~min}$ (Zhang and Klessig 1997). Finally, the NPR1/NIM1/SAI1 protein is an ankyrinrepeat/IkB-like protein that is a positive regulator of SA per- 
ception or PR gene induction (Cao et al. 1997; Ryals et al. 1997; Shah et al. 1997). A. thaliana plants deficient for this function fail to induce PR genes in response to SA treatment or pathogen attack and are more susceptible to disease. Identification of these components has helped tremendously to understand early SA signal transduction. Collectively, they form a model in which a receptor relays increases in SA to latent signaling components, such as kinases, that modify transcription factors that target promoters in SA-induced genes.

Little progress, however, has been made on the identification of SA-responsive genes. The best characterized are the PR genes, which are induced to high levels following treatment with incompatible pathogens or direct application of SA (Eyal et al. 1992; Ward et al. 1991). The response of PR genes to SA is first evident at 6 to $8 \mathrm{~h}$ and rises steadily over several days. On the time scale of induced disease resistance, this response has been considered to be rapid; however, on the time scale of molecular responses to a stimulus, the response is slow. It has been established that PR gene expression is contingent on prior gene induction events (Qin et al. 1994; Uknes et al. 1993).

We set out to identify early SA response genes, which may include transcription factors or signal transduction components for PR gene expression, to learn more about how SA functions at the molecular level. Identification of such genes would make it possible to characterize events involved in the establishment of later responses during the induction of disease resistance. They would also provide an opportunity to characterize the cis elements, transcription factors, and upstream signaling components involved in the primary responses of cells to SA. Identification of similar primary genetic responses of mammalian cells to cytokine induction (Almendral et al. 1988; Beadling et al. 1993; Larner et al. 1986; Lau and Nathans 1987; Zipfel et al. 1989) has revealed scores of genes that have provided a foundation for extensive advances in the understanding of these signaling pathways over the past 10 years.

We describe here a collection of 15 genes that can be induced within 2 to $3 \mathrm{~h}$ of SA treatment. These genes show several distinct response patterns, including induction during an incompatible pathogen interaction. Identification of these genes significantly enhances our understanding of the primary transcriptional responses of cells to SA and provides a large number of new molecular markers for SA action. These data form an important foundation for further elucidation of SA signal transduction.

\section{RESULTS}

\section{Differential display analysis.}

Differential display polymerase chain reaction (ddPCR) analysis (Liang and Pardee 1992) was undertaken to identify immediate-early (IE) SA-induced genes. To enhance the reliable identification of such genes and to reduce the number of false positives, each pair of primers for ddPCR was used with a panel of seven treatments, consisting of the following: (i) $\mathrm{H}_{2} \mathrm{O}, 4 \mathrm{~h}$; (ii) $200 \mu \mathrm{M} \mathrm{SA}, 4 \mathrm{~h}$; (iii) $71 \mu \mathrm{M}$ cycloheximide (CHX), $5 \mathrm{~h}$; (iv) $71 \mu \mathrm{M} \mathrm{CHX,} 5 \mathrm{~h}$ plus $200 \mu \mathrm{M}$ SA after $1 \mathrm{~h} \mathrm{(4}$ h total); (v) $20 \mu \mathrm{M} \mathrm{SA}, 2 \mathrm{~h}$; (vi) $200 \mu \mathrm{M}$ SA, 2 h; (vii) $200 \mu \mathrm{M}$ $\mathrm{SA}, 8 \mathrm{~h}$. Thirty-eight reactions were carried out, with the downstream primers $\mathrm{T}_{12} \mathrm{MG}$ or $\mathrm{T}_{12} \mathrm{MC}$ with the upstream primers AP1-19. Reactions with the primers $\mathrm{T}_{12} \mathrm{MA}$ and $\mathrm{T}_{12} \mathrm{MT}$ were unsuccessful, producing a ladder of DNA fragments. The nomenclature for each ddPCR product was derived from the particular primer combination used to give rise to it (e.g., C6-2 is the second band of interest arising from PCR with primers $\mathrm{T}_{12} \mathrm{MC}$ and $\mathrm{AP} \underline{6}$ ). From the 38 sets of reactions, 60 ddPCR products with interesting display patterns were identified. Fifty-two were recovered for testing on poly(A) mRNA gel blots loaded with the same panel of seven treatments, and the remaining eight products re-amplified poorly and were not pursued. Interesting mRNA expression patterns were confirmed for 15 products, and 12 of these are shown in Figure 1. The remaining three, C3-2, C16-1 (both class I), and $C 2-1$ (class II), produced distinct yet weak signals (data not shown). Signals on Northern (RNA) blots were often poor for ddPCR fragments less than $250 \mathrm{bp}$, but results depended strongly on the steady-state abundance of the specific mRNA. All but four products, C3-2, C6-1, C7-1, and G92 , have been subcloned and sequenced, and their expression patterns verified by Northern analysis. The results are summarized in Table 1. Of the 37 ddPCR fragments that did not demonstrate SA-induced behavior, the patterns that were observed varied from no detectable signal $(n=10)$, constitutive $(n=7)$, constitutive with decreased mRNA accumulation following CHX treatment $(n=6)$, CHX-induced $(n=9)$, SArepressed $(n=1)$, late SA response $(n=1)$, or other pattern $(n$ $=3$ ). Many of these represent potentially interesting genes and require further characterization.

\section{Four classes of early $\mathrm{SA}$ response.}

Several genes had similar expression profiles that could be segregated into four classes of common behavior (Fig. 1). Class I genes (C3-2, C16-1, C18-1, G2-1, G3-1, G8-5, and G9-2) are characterized by (i) little if any detectable mRNA accumulation following SA treatment at 2,4 , or $8 \mathrm{~h}$, (ii) some induction by CHX treatment alone, and (iii) a much greater induction by CHX and SA co-treatment. Superinduction by CHX is a phenomenon that has been widely observed with mammalian IE genes (Almendral et al. 1988; Zipfel et al. 1989) and auxin-induced plant genes (reviewed in Abel and Theologis 1996). In fact, the use of CHX was critical for the detection and isolation of class I genes, which otherwise would not have been observed. Class II genes (C2-1, C6-1, C6-2, C7-1, and G1-1) are characterized by rapid and transient SA induction, with mRNA accumulation at the earliest $(2 \mathrm{~h})$ time point and decreased mRNA levels at later times (4 and 8 h) of SA treatment. $\mathrm{CHX}$ also induced expression of class II genes, and co-treatment with SA produced similar or somewhat greater levels of steady-state mRNA. Class I and II genes are generally similar in their behavior, except that overall mRNA accumulation is greater with class II genes and class I mRNAs showed a distinct, massive accumulation following CHX/SA co-treatment. This CHX/SA superinduction helped to distinguish class I from class II genes, because the mRNA levels from this treatment were distinctly greater than those from either the 4-h CHX or the 2-h SA treatment. Class III is represented by a single gene, G8-1, that showed rapid induction of mRNA accumulation by SA $(2 \mathrm{~h})$ that was sustained through 4 and $8 \mathrm{~h}$. CHX alone did not induce $G 8-1$, and the presence of CHX did not significantly alter induction by SA. Similar to class III, class IV genes (G3-2 and C14-1b) 
showed rapid and sustained induction, with elevated mRNA levels at 2, 4, and $8 \mathrm{~h}$ of SA treatment. CHX not only failed to induce class IV genes but also blocked induction by SA. Overall, most of the genes had comparable sensitivity to SA, with a clear induction at $200 \mu \mathrm{M} \mathrm{SA}$, and little to none at 20 $\mu \mathrm{M}$ SA. Two genes, G8-1 and G3-2, demonstrated greater sensitivity to SA, with $20 \mu \mathrm{M}$ producing mRNA levels comparable to those at $200 \mu \mathrm{M}$.

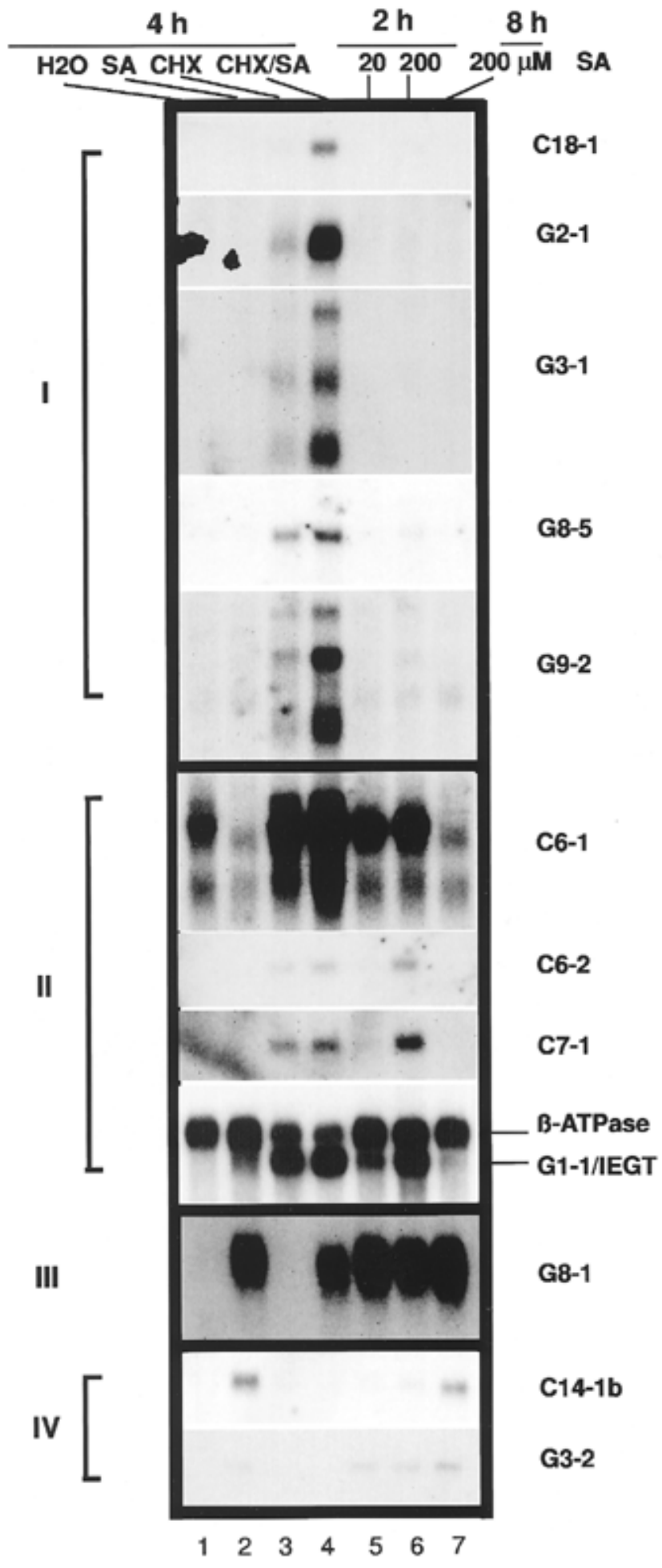

Sequence analysis of available fragments revealed that many of the genes shared no homology with data base sequences (Table 1). These genes may either represent previously unrecognized loci, or the PCR fragments were of insufficient length to reveal a coding region homology. Four sequences did produce noteworthy matches. G1-1 was found to be similar to glucosyltransferases, in particular to plant flavonoid glucosyltransferase. The cloning and characterization of this gene have been reported (Horvath and Chua 1996), and, subsequently, the enzymatic activity has been established as a flavonol-specific glucosyltransferase (D. Horvath and N.H. Chua, unpublished). Clone C16-1 was found to have similarity to several phosphorylase kinases, indicating it may play a role in SA signal transduction. The weakness of this similarity may arise from the small amount of available sequence (209 bp). Clone G8-5 was found to have a strong similarity to an $A$. thaliana retrotransposon and to the endonuclease/integrase region of the maize retrotransposon Hopscotch polyprotein (White et al. 1994); however, the homology was to the minus strand of G8-5. Although a match to the minus strand is dubious, the match is strong, including several highly conserved residues. Moreover, there are reports of a highly related transposon, Tntl, being activated by pathogen infection and SA (Moreau-Mhiri et al. 1996; Mhiri et al. 1997). A perfect match was found between clone $C 18-1$ and the previously cloned tobacco gene ethylene response element binding protein 1 (EREBP1) (Ohme-Takagi and Shinshi 1995). When the PCR fragment was used to retrieve a full-length cDNA, two related sequences were recovered. One was identical to EREBP1 with minor differences in the $5^{\prime}$ and $3^{\prime}$ untranslated region, and the other, a partial cDNA clone lacking approximately $150 \mathrm{bp}$ of $5^{\prime}$ sequence, was $96 \%$ identical at the nucleotide level within the available coding region. A full-length cDNA clone was obtained for the clone G8-1; however, no significant data bases matches were evident with the additional sequence information.

\section{SA induction kinetics.}

The kinetics of induction were examined in detail through time course experiments for representatives of each expression class. Although no SA-induced signal was apparent on poly(A) mRNA gel blots (Fig. 1) with the ddPCR fragment for any class I gene, enhanced conditions with the full-length cDNA of $C 18-1 / E R E B P 1$ for probe made it possible to visualize a signal (Fig. 2). In fact, SA did induce a very rapid and transient increase in C18-1/EREBP1 mRNA levels, first apparent at $10 \mathrm{~min}$, peaking at $2 \mathrm{~h}$, and decaying rapidly to

Fig. 1. Four classes of salicylic acid (SA)-induced early genes. Northern (RNA) analysis of genes identified by differential display (dd). Gel-purified DNA fragments produced by dd polymerase chain reaction (PCR) were either used directly for random-primed labeling and probing of Northern filters (e.g.; C7-1, C6-1, and G9-2) or first subcloned and released by restriction digest. Each lane contains $1 \mu \mathrm{g}$ of poly(A) mRNA from cultured tobacco cells treated with (i) $\mathrm{H}_{2} \mathrm{O}, 4 \mathrm{~h}$; (ii) $200 \mu \mathrm{M} \mathrm{SA}, 4$ h; (iii) $71 \mu \mathrm{M}$ cycloheximide (CHX), $5 \mathrm{~h}$; (iv) $71 \mu \mathrm{M}$ CHX, 5 h plus 200 $\mu \mathrm{M} \mathrm{SA}$ after $1 \mathrm{~h}$ (4 h total); (v) $20 \mu \mathrm{M} \mathrm{SA}, 2 \mathrm{~h}$; (vi) $200 \mu \mathrm{M} \mathrm{SA}, 2 \mathrm{~h}$; (vii) $200 \mu \mathrm{M} \mathrm{SA}, 8 \mathrm{~h}$. One blot was sequentially hybridized with the $\mathrm{Gl}$ 1 fragment and the $\beta$-ATPase gene as a loading control probe. Response classes (I-IV) are indicated on left of autoradiograms. mRNA sizes are given in Table 1. 
background levels by $4.5 \mathrm{~h}$. The class II gene C6-2 demonstrated similar kinetics, with induction apparent within $10 \mathrm{~min}$ and peak levels at approximately $1.5 \mathrm{~h}$ that decreased to background by $4 \mathrm{~h}$. Previously, we have described the induction of another class II gene, G1-1/IEGT (Horvath and Chua 1996), that was induced slightly later at 20 to $30 \mathrm{~min}$ and reached a peak of expression at around $3 \mathrm{~h}$. The class III gene G8-1 was first detected between 30 and 60 min and reached a plateau at 2 to $2.5 \mathrm{~h}$ that was maintained for at least $12 \mathrm{~h}$. G3-2, a class IV gene, was not detectably activated prior to $2 \mathrm{~h}$, but between 2 and $12 \mathrm{~h}$ mRNA levels increased steadily. Another class IV gene, $C 14-1 b$, demonstrated a different response profile. Induction was apparent at 2 to $2.5 \mathrm{~h}$, as with G3-2; however, a clear maximum level of mRNA accumulation was apparent at

Table 1. Summary of early salicylic acid (SA)-induced genes identified by differential display polymerase chain reaction (ddPCR)

\begin{tabular}{|c|c|c|c|c|c|}
\hline ddPCR product & Response class & Fragment size (bp) & Approximate mRNA Size (nt) ${ }^{a}$ & Homology $^{b}$ & Blastx score $^{c}$ \\
\hline C3-2 & I & 190 & $6,000 / 2,800 / 850$ & Not cloned & \\
\hline C16-1 & I & 203 & $5,000 / 4,000^{\mathrm{d}}$ & Phosphorylase kinase gamma (rat) ${ }^{\mathrm{e}}$ & $5 \times 10^{-3}$ \\
\hline C18-1 & I & 426 & 1,200 & EREBP-1 (Nicotiana tabacum $)^{\mathrm{f}}$ & $1.3 \times 10^{-70}$ \\
\hline G2-1 & I & 524 & 520 & None & \\
\hline G3-1 & I & 276 & $2,000 / 1,000 / 700$ & None & \\
\hline$G 8-5$ & I & 437 & 1,500 & $\begin{array}{l}\text { Retrotransposon polyprotein } \\
\text { (Arabidopsis thaliana })^{\mathrm{g}}\end{array}$ & $7.6 \times 10^{-47}$ \\
\hline$G 9-2$ & I & 230 & $4,000 / 2,000 / 1,600$ & Not cloned & \\
\hline$C 2-1$ & II & 382 & 5,00 to 6,000 & None & \\
\hline C6-1 & II & 430 & $2,000 / 1,300$ & Not cloned & \\
\hline C6-2 & II & 174 & $1,300 / 1,000$ & None & \\
\hline C7-1 & II & 430 & 800 & Not cloned & \\
\hline G1-1 & II & 297 & 1,600 & $\begin{array}{l}\text { Plant flavonol glucosyltrans- } \\
\text { ferases } / I E G T^{\mathrm{h}}\end{array}$ & $3.0 \times 10^{-25}$ \\
\hline$G 8-1$ & III & 400 & 550 & None & \\
\hline$C 14-1 b$ & IV & 298 & 1,000 & None & \\
\hline G3-2 & IV & 282 & 5,000 & None & \\
\hline
\end{tabular}

a Slashes separate multiple messages of different sizes.

${ }^{\mathrm{b}}$ Homology was assessed by a minimum Blastx value of $5 \times 10^{-3}$

c The score is the Smallest Sum Probability value (Altschul et al. 1990).

d The two transcripts detected with the cloned ddPCR product had different patterns of expression and may represent related sequences encoded by different genes.

e Cawley et al. 1988 .

${ }^{f}$ Ohme-Takagi and Shinshi 1995.

g Bevan et al. (1997); also maize cv. Hopscotch (White et al. 1994).

h twil, (Truesdale 1996), IEGT, (Horvath and Chua 1996).

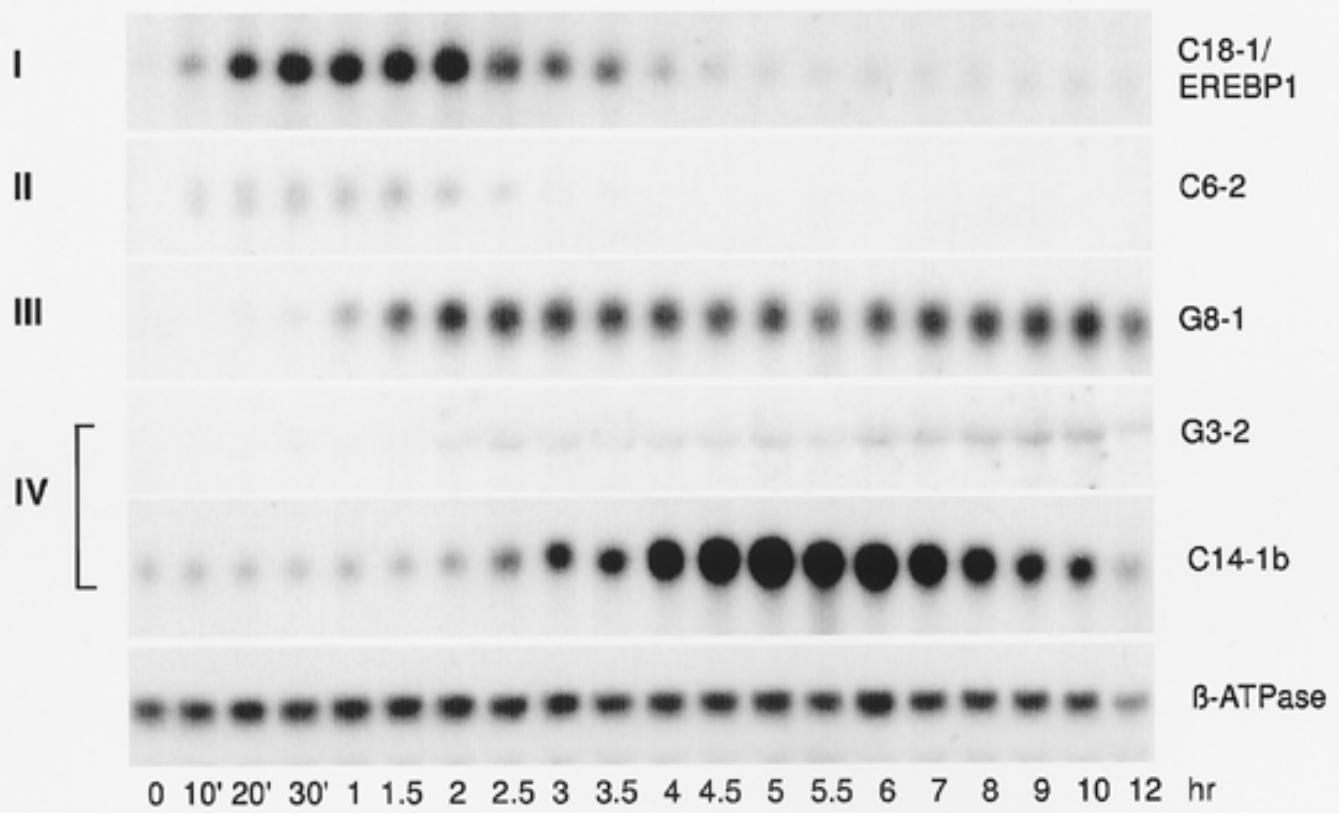

Fig. 2. Time course of salicylic acid (SA)-induced gene expression. Northern (RNA) analysis of representative differential display (dd) genes following treatment of cultured tobacco cells with SA for the indicated time (in hours, except lanes $2-4$, which refer to 10,20 , and 30 min). Twenty micrograms of total RNA was loaded per lane. Blots were hybridized with dd polymerase chain reaction (PCR) fragments indicated at right or with the $\beta$-ATPase gene as a loading control probe. Autoradiogram exposure times were optimized for each gene. Signal for C18-1/EREBP1 was enhanced with the full-length cDNA as probe. Labels on left indicate response class (I-IV). 
approximately $5 \mathrm{~h}$, with a steady decline thereafter. The rapid and transient responses of class I and II genes were most similar to classical mammalian IE gene responses, whereas classes III and IV, though early, appeared to be regulated by a different mechanism.

\section{CHX sensitivity.}

To verify the IE response profile, the expression patterns of these SA-induced genes were analyzed further by testing the effect of CHX, a protein synthesis inhibitor, in time course experiments. Consistent with data from Figures 1 and 2, these experiments more fully illustrate the differences in the CHX response of the different gene classes. As shown in Figure 3, the class I genes $C 18-1 / E R E B P 1$ and $G 2-1$ failed to accumulate significant levels of mRNA following treatment of cells with $\mathrm{H}_{2} \mathrm{O}$, and $C 18-1$ showed only a small increase at 0.5 and
$1 \mathrm{~h}$ of SA (Fig. 3A). Both genes showed some steady accumulation of mRNA following treatment with $\mathrm{CHX}$ alone, and, following $\mathrm{CHX}$ and SA co-treatment, a massive increase in mRNA level was observed, beginning at $0.5 \mathrm{~h}$ and increasing through $24 \mathrm{~h}$. The decrease in signal at late times of CHX treatments is offset by lower amounts of RNA loaded in these lanes (compared with the $\beta$-ATPase signal). A similar response profile was observed for G8-5 (data not shown). The class II gene C6-2 showed no induction by $\mathrm{H}_{2} \mathrm{O}$ and a very weak induction following SA treatment. In general, the small fragment size (174 bp) of C6-2 made obtaining high quality autoradiograms difficult. Expression of the C6-2 gene was clear, however, following $\mathrm{CHX}$ or $\mathrm{CHX} / \mathrm{SA}$ treatment, and, in contrast to the class I genes, co-treatment with $\mathrm{CHX}$ and SA did not produce a steady-state level of mRNA that was significantly greater than produced by $\mathrm{CHX}$ treatment alone.

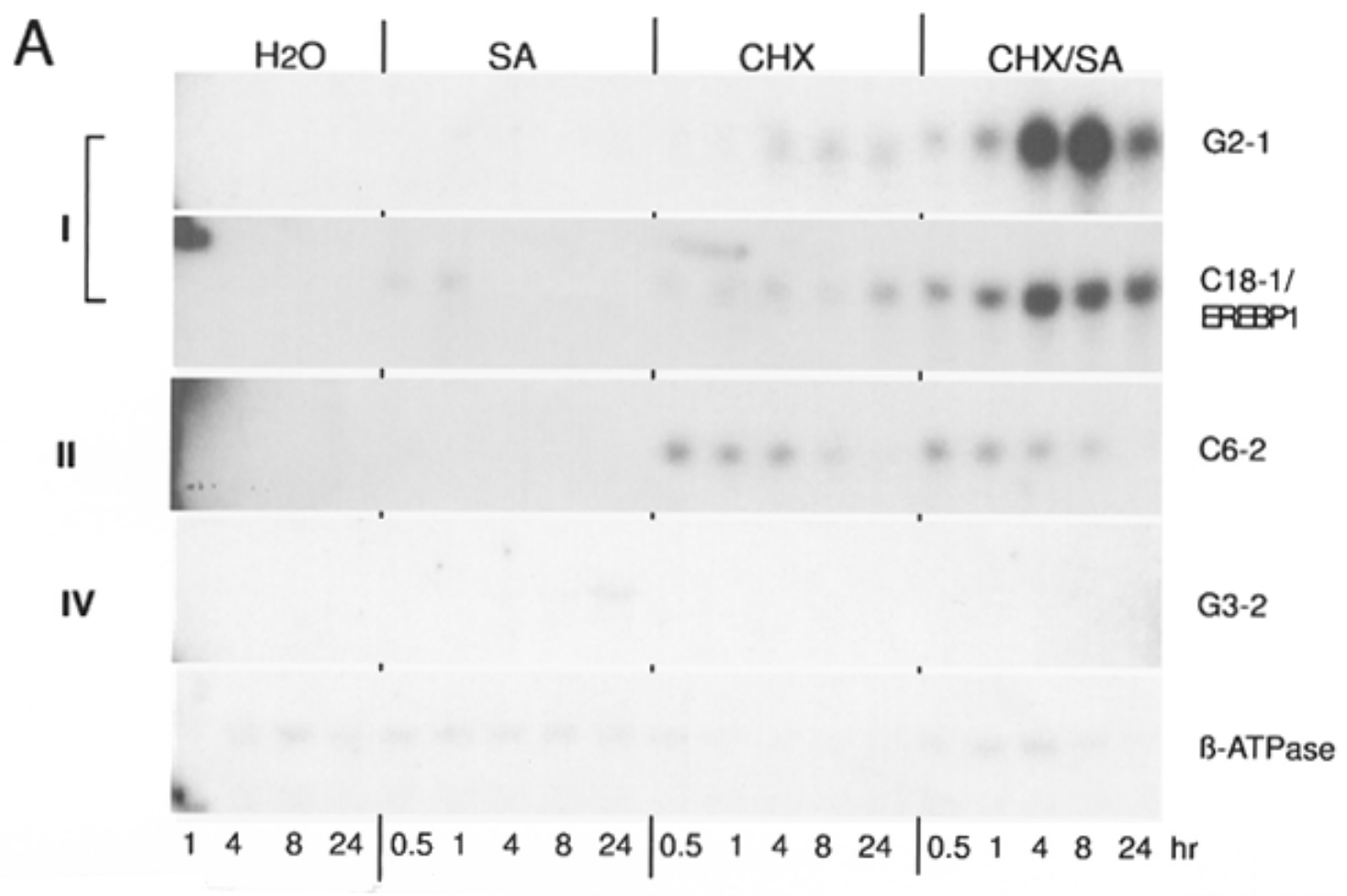

B
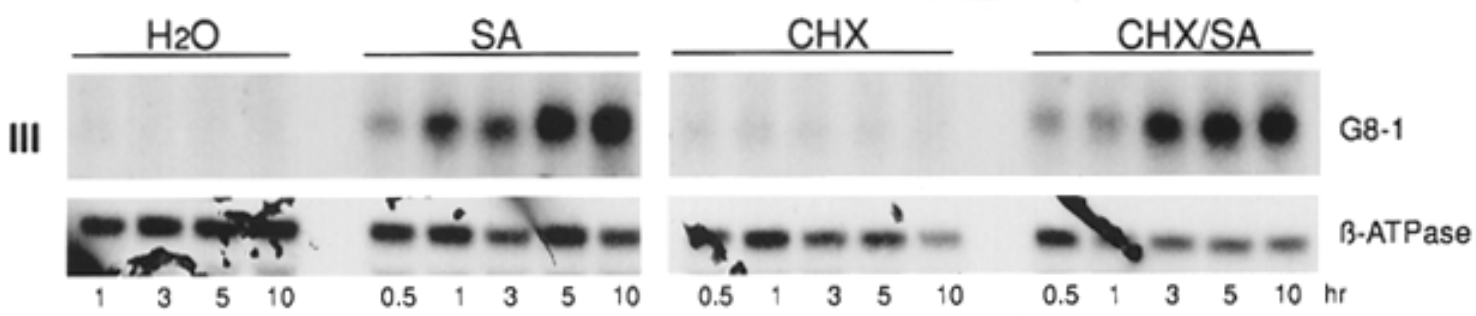

Fig. 3. Effect of cycloheximide (CHX) on time-dependent accumulation of mRNA following salicylic acid (SA) treatment. Northern (RNA) analysis of representative differential display (dd) genes following treatment of cultured tobacco cells with $\mathrm{H}_{2} \mathrm{O}$ (lanes 1-4), 200 $\mu \mathrm{M}$ SA (lanes 5-9), 71 $\mu \mathrm{M}$ CHX (lanes 10-14), or $71 \mu \mathrm{M}$ CHX plus $200 \mu \mathrm{M}$ SA (lanes 15-19) for (A) $0.5,1,4,8$, or 24 , (B) or $0.5,1,3,5$, or 10 h. CHX pretreatments were initiated $1 \mathrm{~h}$ prior to the start of each time course; thus, CHX incubation times are $1 \mathrm{~h}$ longer than indicated times. Twenty micrograms of total RNA was loaded per lane. Blots were hybridized with dd polymerase chain reaction (PCR) fragments indicated at right or with the $\beta$-ATPase gene as a loading control probe. Autoradiogram exposure times were optimized for each gene. Labels on left indicate response class (I-IV). 
Figure 3B shows results from a separate time course experiment with $G 8-1 . \mathrm{H}_{2} \mathrm{O}$ did not produce any induction of $G 8-1$, whereas SA treatment induced expression within $30 \mathrm{~min}$ as above (Fig. 2). CHX treatment alone produced no accumulation of $68-1$, and the co-treatment of CHX and SA produced mRNA levels comparable to those of SA treatment alone. Thus, G8-1 appears to be completely insensitive to CHX. The class IV gene G3-2 (Fig. 3A) showed an increase in mRNA levels at late times ( 8 and $24 \mathrm{~h}$ ) of SA treatment that was blocked in the presence of CHX. No induction was observed following treatment with $\mathrm{H}_{2} \mathrm{O}$ or $\mathrm{CHX}$ alone. This behavior is similar to that of PRIa (Horvath and Chua 1996; Uknes et al. 1993), a late SA-induced gene.

\section{Chemical specificity.}

The specificity for induction by SA was tested by treating tobacco cells with a range of SA analogs and plant signaling compounds at 0.1 or $1 \mathrm{mM}$ for approximately $2.5 \mathrm{~h}$. The results shown in Figure 4 demonstrate a wide range in the re- sponses of individual genes. Among the SA analogs, acetyl SA (ASA, aspirin), benzoic acid (BA), and 4-hydroxybenzoic acid (4HBA) responses generally reflected the ability of the analog to substitute for SA in other cellular responses (Yalpani et al. 1991; Yang and Klessig 1996). ASA, typically equally effective as SA, and SA induced all the genes to a similar degree. BA, a partially active analog, also induced expression, but the inactive analog 4HBA failed to induce all but C6-2. An interesting distinction among the responses is that G8-1 and G3-2 both showed a high sensitivity to SA, ASA, and BA, showing equal or greater induction at $0.1 \mathrm{mM}$ versus $1 \mathrm{mM}$, whereas C18-1/EREBP1 and C6-2 showed greater induction at $1 \mathrm{mM}$. $C 14-1 b$ showed little to no response to SA or ana$\operatorname{logs}$ in this time frame. All other genes displayed specificity for induction by active SA analogs, except for C6-2, which may respond with the behavior of an electrophile responsive gene (Ulmasov et al. 1994). Among other compounds tested, thiamine, a strong inducer of PR genes (Asselin et al. 1985), did not produce a response from any of the genes tested. MJ, a

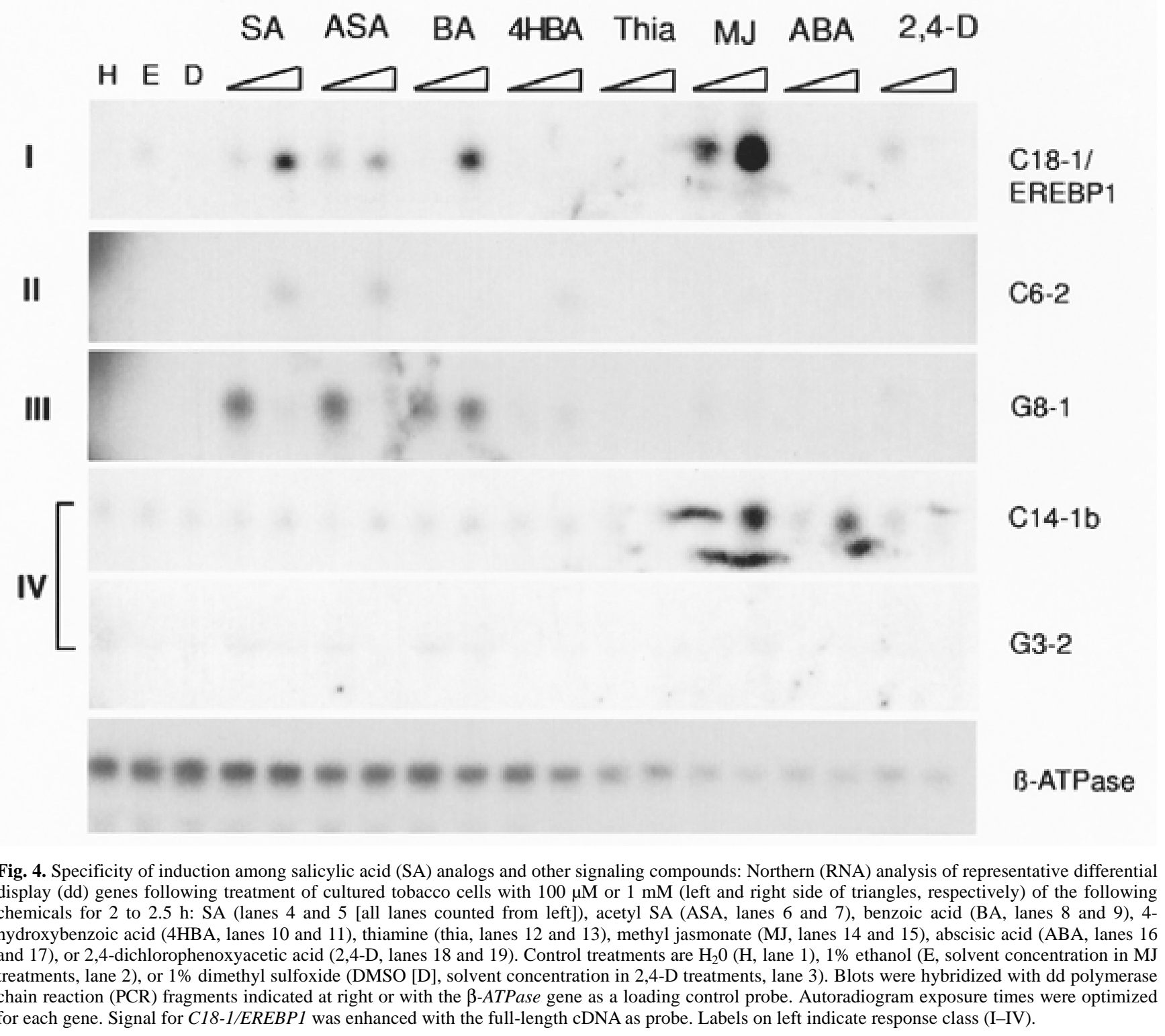


plant compound involved in wound responses, was able to induce expression of several genes, including C18-1/EREBP1, $C 14-1 b$, and G3-2. In fact, MJ was the most effective inducer for $C 18-1 / E R E B P 1$ and $C 14-1 b$. Interestingly, $C 14-1 b$ was the only gene that could be induced by ABA, a signal molecule involved in wound responses and drought and cold stress. Several genes, including those for proteinase inhibitors and lipoxygenase (Hildmann et al. 1992; Melan et al. 1993; Xu et al. 1993), are known to be under dual regulation by MJ and ABA. A similar mode of regulation may be in effect with $C 14-1 b$. The auxin 2,4-D induced several genes including C18-1/EREBP1 and C6-2. Thus, although several of the ddPCR genes displayed a trend toward activation by active SA analogs, all but G8-1 were significantly induced by additional plant compounds, suggesting additional roles for these genes in other response pathways.

A more detailed examination of the responses of $\mathrm{Cl}$ $1 / E R E B P 1$ and $G 8-1$ to inducing compounds was made by treating tobacco cells with a range of concentrations from 0.1 $\mu \mathrm{M}$ to $2 \mathrm{mM}$. The results are shown in Figure 5. As above, SA and ASA produced similar profiles of response from each gene, but the extended range of concentration clearly demonstrated the difference in sensitivity of C18-1/EREBP1 and G81. Quantitation of the SA response is shown in Figure 6. Whereas C18-1/EREBPI and the previously characterized IEGT (Horvath and Chua 1996) have a narrow response zone, a wide range of SA concentrations is able to activate expression of G8-1. The concentration of SA required for half of the maximum level of $C 18-1 / E R E B P 1$ or IEGT expression is 100 to $150 \mu \mathrm{M}$, whereas the half maximal concentration for $G 8-1$ is approximately $1 \mu \mathrm{M}$. Similar sensitivity was demonstrated by G3-2 (data not shown). As seen previously (Horvath and

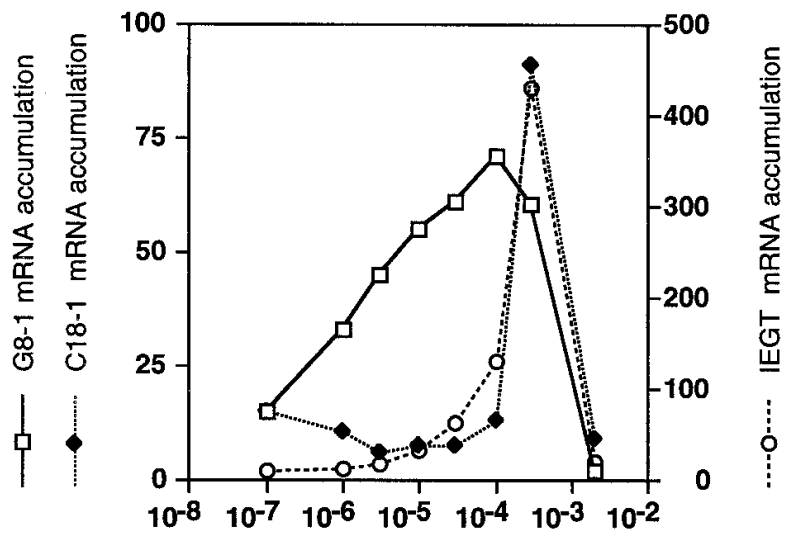

SA (M)

Fig. 6. Sensitivity to salicylic acid (SA) concentration of several SAinduced genes: Graphic representation of mRNA accumulation of G8-1 (open squares), C18-1/EREBP1 (black diamonds), and IEGT (open circles) in response to 2 to $2.5 \mathrm{~h}$ of incubation of cultured tobacco cells with a range of SA concentrations. RNA gel blots were quantitated by phosphorimaging analysis and normalized relative to the $\beta$-ATPase gene loading control (not shown).
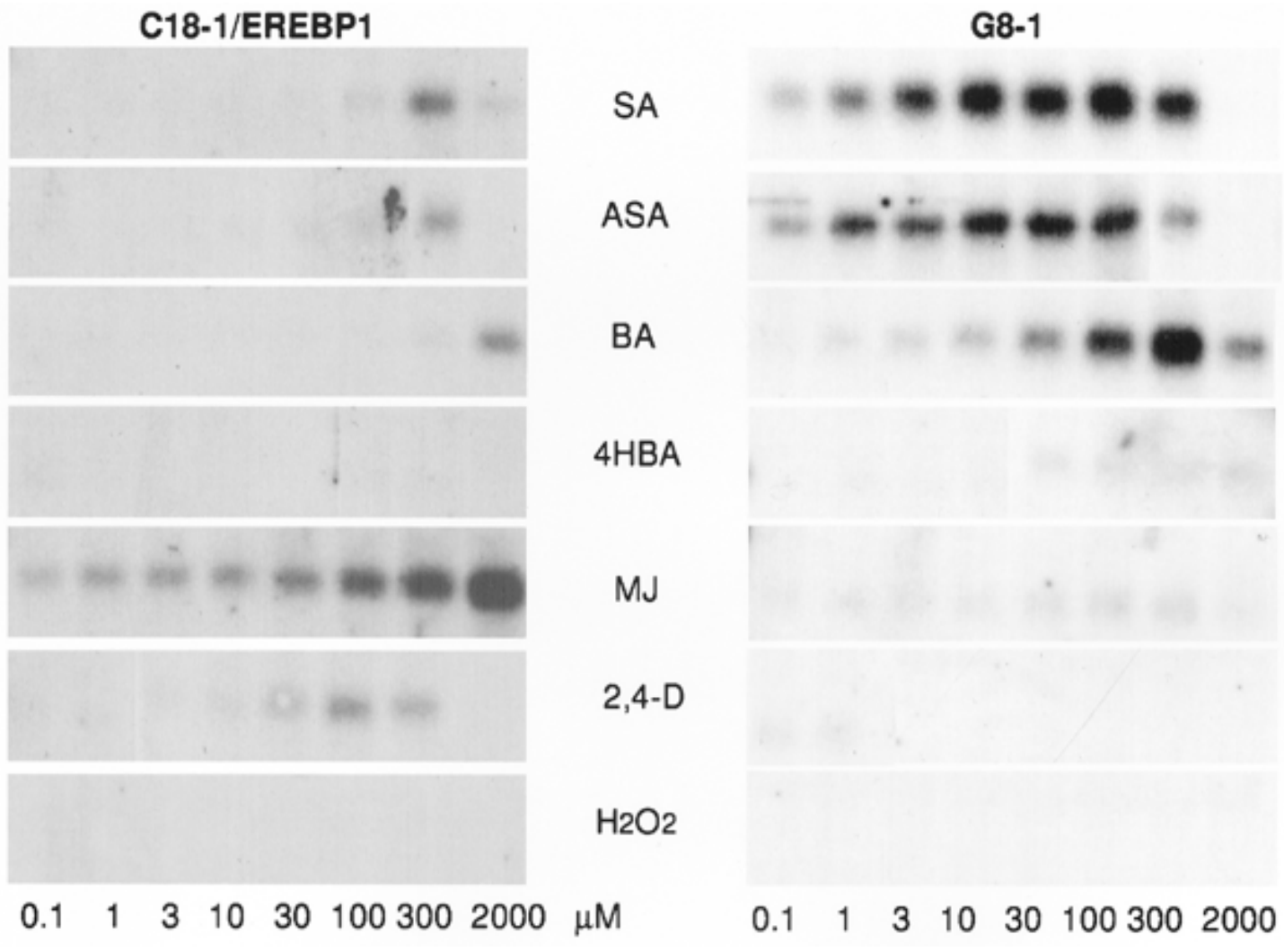
trations of salicylic acid (SA), acetyl SA (ASA), benzoic acid (BA), 4-hydroxybenzoic acid (4HBA), thiamine (Thia), methyl jasm onate (MJ), abscisic acid (ABA), 2,4-dichlorophenoxyacetic acid (2,4-D), or $\mathrm{H}_{2} \mathrm{O}_{2}$ for 2 to $2.5 \mathrm{~h}$. Concentrations were $0.1,1,3,10,30,100,300 \mu \mathrm{M}$ or $2 \mathrm{mM}$, as indicated. 
Chua 1996), millimolar concentrations of some compounds, including SA, ASA, and 2,4-D, are toxic to cells, resulting in lower overall RNA levels. Tobacco cells are less sensitive to $\mathrm{BA}$, as demonstrated by the higher concentrations required to activate gene expression to the same level activated by SA or ASA and by a decreased phytotoxic effect in the millimolar range. 4HBA did not induce C18-1/EREBP1 expression and may have produced a very low level of G8-1 expression. However, the weak G8-1 signal in some lanes of 4HBA, MJ, and 2,4-D treatments resulted in part from a larger total amount of RNA, as revealed by the $\beta$-ATPase signal (data not shown). Consistent with Figure 4, MJ was a very effective inducer of $C 18-1 / E R E B P 1$, producing increases in steadystate mRNA levels at concentrations of $0.1 \mu \mathrm{M}$. Transcript levels increased gradually through $30 \mu \mathrm{M}$ and then steeply from $100 \mu \mathrm{M}$ to $2 \mathrm{mM}$. Auxin also induced C18-1/EREBP1 at concentrations between 30 and $300 \mu \mathrm{M}$, whereas $\mathrm{H}_{2} \mathrm{O}_{2}$ produced no response. In contrast, G8-1 was not induced to any significant extent by $\mathrm{MJ}, 2,4-\mathrm{D}$, or $\mathrm{H} 2 \mathrm{O} 2$, defining it as the most sensitive and selective SA-induced gene characterized to date.

\section{Pathogen-induced expression.}

The behavior of genes during a defense response in intact plants was examined by causing a TMV-induced HR in tobacco leaves. Results are shown in Figure 7. Tobacco plants were mock- or TMV-inoculated on a single leaf, and mRNA levels were examined at various time points over a 3-day period. Both C18-1/EREBPI (class I) and G1-1/IEGT (class II) were expressed at higher levels in TMV-infected tobacco plants than in control plants between 28 and $56 \mathrm{~h}$. The kinetics of activation closely follow the timing of induced SA biosynthesis, which begins at between 24 and 36 hours post inoculation (hpi; Malamy et al. 1990). By 74 hpi with TMV, however, mRNA levels from both genes had returned to basal levels equivalent to those in control plants. The $G 8-1$ gene was also expressed at higher levels in TMV-infected leaves as early as $28 \mathrm{hpi}$, and these levels remained elevated through $74 \mathrm{~h}$. No basal G8-1 mRNA was observed in control plants. As a reference, the behavior of the PRla gene was examined. Levels of PRla mRNA began to accumulate at 32 hpi and rose steadily throughout $74 \mathrm{~h}$, whereas no PRla mRNA was detected in control plants. These results demonstrate that the general kinetics of gene responses observed in SA-treated cultured tobacco cells are borne out in TMV-infected tobacco plants. Class I and II genes are still early and transient, the class III gene is rapid and sustained, and the late SA-induced PRla gene is expressed later and increases over several days. No class IV genes have yet been characterized for induction during a defense response.

\section{DISCUSSION}

In order to elucidate the transcriptional responses of plant cells to the signal molecule SA, we have identified and characterized 15 SA-induced genes with differential display. Unequivocal identification of these genes was facilitated by the use of a panel of seven different treatments, including the presence and absence of SA, three time points of SA treatment, two concentrations of SA, and the effect of CHX treatment, to carry out PCR and Northern analysis. This approach diminished the number of false positive results and allowed us to identify genes with a variety of SA responses. The target genes identified fall into four different SA response classes.

Class I response genes, exemplified by $C 18-1 / E R E B P 1$, and class II genes, exemplified by $C 6-2$ and IEGT, are characterized by rapid and transient activation in response to continuous exposure to SA. In planta, similar kinetics were observed during the development of an HR. C18-1/EREBP1 was induced in the same time frame as initiation of SA biosynthesis, i.e., rapidly in response to elevated levels of SA. The response was also transient, with abatement by $74 \mathrm{~h}$. The extended response time, relative to cultured cells treated with SA, likely reflects the heterogeneous population of leaf cells responding in sequential zones around pathogen entry points. A tobacco genotype (nn) that is isogenic except for its ability to initiate a TMV defense

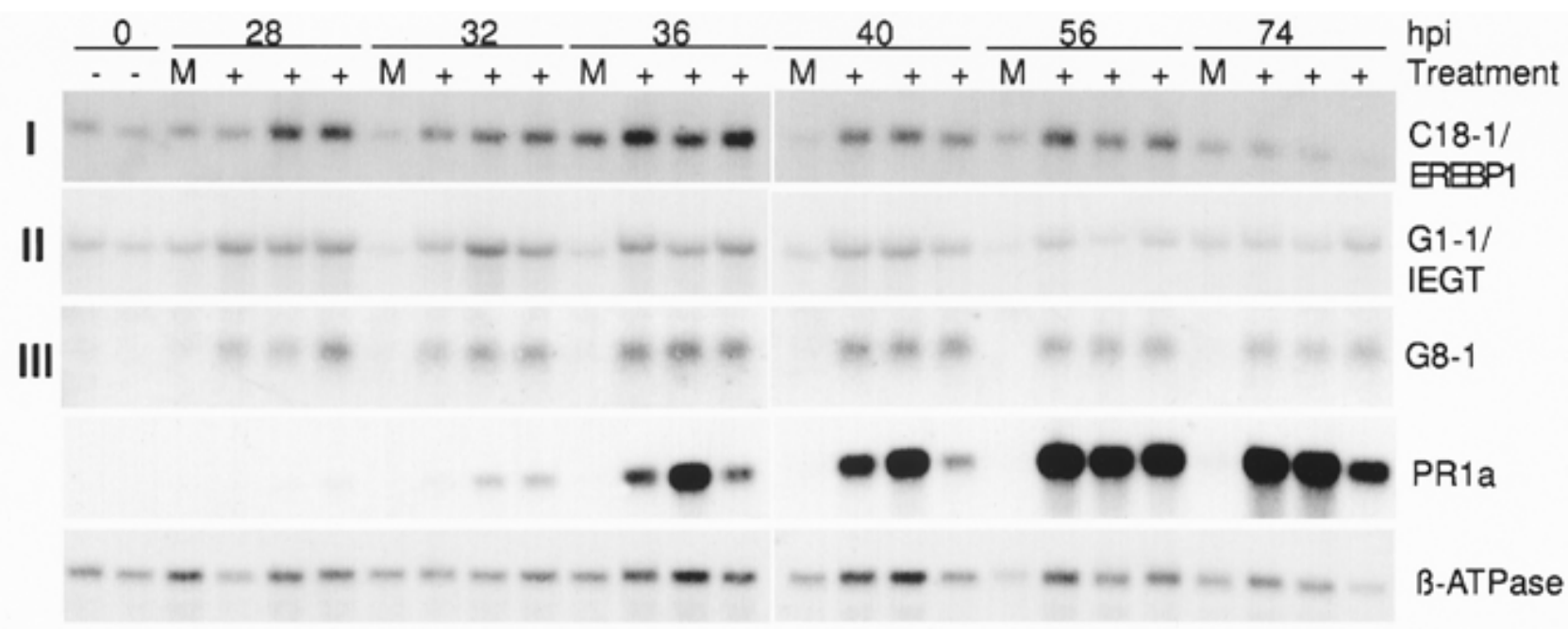

Fig. 7. Induction time course of gene expression in tobacco plants inoculated with tobacco mosaic virus (TMV): Northern (RNA) analysis of $C 18$ 1/EREBP-1, IEGT, and G8-1 mRNA accumulation in leaves of resistant tobacco plants inoculated with TMV (+) or mock-inoculated (m) and harvested at $28,32,36,40,56$, and $74 \mathrm{~h}$ post inoculation (hpi). Leaves from two uninoculated plants (-) were sampled at start of treatment period. Each lane represents a separate, individual plant. RNA gel blots were also probed with the PRla gene and the $\beta$-ATPase gene as a loading control. Labels on left indicate response class (I-IV). 
response did not show any increase in C18-1/EREBP1 expression following TMV infection (data not shown).

The sensitivity of class I and II genes to $\mathrm{CHX}$ suggests at least three possible mechanisms of regulation. (i) Promoter activity is subject to negative regulation by a labile signal transduction component with an inhibitory function such as SAI (Jupin and Chua 1996) or by a transcriptional repressor. When this protein is not synthesized, the balance of regulation shifts toward increased mRNA production. (ii) An mRNA instability determinant is mediated by a labile protein that facilitates mRNA degradation. When this protein is not synthesized, steady-state mRNA levels increase. (iii) $\mathrm{CHX}$ directly stimulates expression of these genes by activating signaling components. Further work is required to distinguish between these mechanisms. The strict control of this class of mRNAs suggests that they may encode regulatory molecules. This conclusion was confirmed by the finding that one of the class I genes, $C 18-1$, is EREBP1, a tobacco DNA binding protein that interacts with a sequence that confers ethylene regulation on PR gene promoters (Ohme-Takagi and Shinshi 1995). Recently, it has been demonstrated in tomato that EREBP proteins directly interact with Pto kinase, an $\mathrm{R}$ gene specifying resistance to Pseudomonas syringae pv. tomato (Zhou et al. 1997), indicating that these proteins may play a pivotal role in the establishment of defense responses. Another example is the tobacco gene $m y b l$, an $m y b$-family transcription factor that can bind in vitro to a sequence found in the PRla promoter (Yang and Klessig 1996). mybl was induced within 15 min of SA treatment with a peak level of mRNA at approximately 30 min, decreasing to background levels by 6 to $12 \mathrm{~h}$. Following a 30-min treatment with CHX, mybl was induced to levels comparable to those induced by SA, and co-treatment by $\mathrm{CHX}$ and SA caused a greater level of accumulation, to the degree observed with our class II genes. One difference between $m y b l$ and class I-III genes is in the kinetics of induction following TMV infection. Whereas class I-III genes showed elevated steady-state mRNA levels by $28 \mathrm{hpi}$, mybl was not detected until 36 hpi. Moreover, mybl levels, although declining, were evident through at least 72 hpi. Differences in experimental design may account for this discrepancy.

Another example of class II SA-induced behavior is the viral as- 1 promoter element. Interestingly, SARP binding to as1 is induced by treatment not only with SA, but also CHX, and CHX/SA co-treatment produced an even greater extent of DNA binding. These data show a strong correlation between DNA binding and transcription activation and suggest that the as- 1 element is usurping a cell function for endogenous gene regulation in response to $\mathrm{SA}$.

Class II genes are distinguished from class I genes by greater steady-state mRNA levels following SA treatment, whereas class I genes are low abundance, and class II genes show less of a drastic superinduction by CHX and SA cotreatment. Similar mechanisms of regulation may function for class I and II genes, perhaps with an added level of regulation for class I genes to maintain low abundance. For example, because the kinetics of the SA response are similar, class I and II genes may have similar promoter regulation through common cis elements and, additionally, class I genes may have lower mRNA stability. A precedent for this type of tight regulation has been established for several mammalian IE genes, including $c$-fos and c-myc (Almendral et al. 1988).
With only one representative class III gene, it is difficult to generalize on the possible mechanisms of regulation. However, G8-1 has several important and unique features that clearly distinguish it from other SA-induced genes. It is induced rapidly after SA treatment, yet lags behind class I and II responses by 20 to $30 \mathrm{~min}$. It is insensitive to $\mathrm{CHX}$, indicating no common negative regulatory mechanism with classes I and II. Moreover, once activated, G8-1 mRNA is maintained at a continuous level. Yet, the most remarkable feature about G8-1 is its tremendous sensitivity to SA concentration. With a halfmaximal effective concentration of $1 \mu \mathrm{M}, G 8-1$ is 100 to 150 times more sensitive than all other SA-induced genes and enzyme activities described here and elsewhere (Du and Klessig 1997; Horvath and Chua 1996; Yalpani et al. 1992). Because the sensitivity of G8-1 is similar to that of SABP2 (Du and Klessig 1997), G8-1 may be a direct target of SABP2 regulation.

Class IV genes are characterized by induction after 2 to $3 \mathrm{~h}$ of SA treatment. Although rapid, this response is clearly distinct from that of both the class I-III genes, which require new protein synthesis for their expression, and the PR genes, which are typically late responding. However, C14-1b, G3-2, and PR genes are all blocked for induction by SA in the presence of CHX (Horvath and Chua 1996) and represent a second wave of SA responses. Class III responses are somewhere between typical IE responses and this second wave. Collectively, each class marks a progression into establishing a new cellular program. As found for PR genes, it is expected that some class I-III genes encode transcription factors that direct the synthesis of class IV genes.

Several of the genes investigated in this study, irrespective of their SA response classification, were found to be induced by other compounds. EREBP1, for example, was originally identified as a protein that is induced by ethylene and binds to ethylene response elements in defense genes (Ohme-Takagi and Shinshi 1995). A 16-h treatment of cultured tobacco cells with ethephon, a compound that breaks down to release ethylene and other compounds that affect plant defense (Lawton et al. 1994), was used to initially characterize EREBP1 expression. Here we find $C 18-1 / E R E B P 1$ to be induced much more rapidly by $\mathrm{SA}$, auxin, and, most effectively, MJ, with mRNA levels returning to undetectable levels by $4 \mathrm{~h}$ of SA treatment. Because this response to $\mathrm{SA}$ is much faster, a possible sequential relationship between ethylene and SA could exist. In fact, it has been demonstrated in A. thaliana that ethephon induction of defense genes requires $\mathrm{SA}$; ethylene induction, however, does not (Lawton et al. 1994). Therefore, a definitive sequence of defense signals involving first ethylene and then SA does not appear to exist, consistent with the observation that basic PR genes, which contain the EREBP1 binding site, are not induced by SA treatment to the same degree as by ethylene (Eyal et al. 1992). The most striking aspect of the induction of ddPCR genes by other compounds is the recurrent, common ability of SA, auxin, and MJ to induce the same genes rapidly. These data are consistent with previous observations not only with plant genes but also with several pathogen genes expressed in plants (Horvath and Chua 1996; Jepson et al. 1994; Kim et al. 1993; Xiang et al. 1996; Zhang and Singh 1994). A common feature of those that have been examined, including as-1, ocs, nos, and GNT35, is the presence of a tandem pair of ACGT promoter sequences, referred to as an $a s$-1-like element, that have been demonstrated to mediate 
some of the responses. These sequence elements are known to be regulated by bZIP-type transcription factors; however, due to the large number of bZIP proteins in plants, it is not known which particular homo- or hetero-dimers of bZIP mediate which particular response. Further experiments will elucidate how signaling in response to these three stimuli converge on the same target genes with such rapid kinetics. Recently, we have identified a strong as-1-like sequence element in the IEGT promoter, consistent with the ability of this gene to be induced by $\mathrm{SA}, \mathrm{MJ}$, and auxin.

The utility of classifying the behavior of different SAresponsive genes is to understand common regulatory mechanisms. By careful examination of the genes we have identified, we have sorted them into common classes of behavior that appear to share common means of regulation. By obtaining genomic clones of our ddPCR fragments, we can examine what promoter sequence elements mediate these responses and what transcription factors and upstream signaling components function in this role. We would predict that common motifs would be present among genes in a particular response class. Interesting questions to resolve are what promoter element confers SA-specific expression on G8-1 and how both G8-1 and G3-2, which have distinctly different kinetics and sensitivity to $\mathrm{CHX}$, respond so acutely to very low concentrations of SA. We have also demonstrated that a large number of genes that participate in the responses of cells to SA have not yet been identified. Even among those identified in the present study, few have an obvious function based on sequence similarity. Further characterization of these genes will continue to elucidate the mechanisms by which SA regulates plant cell processes and gene expression. Ultimately, we expect to define a sequential series of gene induction events that establish a plant's ability to ward off disease.

\section{MATERIALS AND METHODS}

\section{Plant material.}

Tobacco plants and BY-2 cultured tobacco cells were grown and chemically treated as previously described (Horvath and Chua 1996). Chemical stocks were prepared in $\mathrm{H}_{2} \mathrm{O}$ (SA, ASA, BA, 4HBA, $\mathrm{H}_{2} \mathrm{O}_{2}$ ) or dimethyl sulfoxide (DMSO; 2,4-D, MJ). MJ was alternatively prepared in ethanol as indicated in Figure 4 and diluted for a final DMSO concentration of $1 \%$ in all treatments. Following treatments, tobacco cells were collected, dried by vacuum filtration, and frozen in liquid nitrogen.

\section{Differential display.}

Cultured tobacco cells were treated with one of seven regimes on the fifth day of subculture in preparation for differential display: (i) $\mathrm{H}_{2} \mathrm{O}, 4 \mathrm{~h}$; (ii) $200 \mu \mathrm{M} \mathrm{SA}, 4 \mathrm{~h}$; (iii) $71 \mu \mathrm{M}$ $(20 \mu \mathrm{g} / \mathrm{ml}$ ) CHX, $5 \mathrm{~h}$; (iv) $71 \mu \mathrm{M} \mathrm{CHX}, 5 \mathrm{~h}$ plus $200 \mu \mathrm{M}$ SA after $1 \mathrm{~h}$ (4 h total); (v) $20 \mu \mathrm{M} \mathrm{SA}, 2 \mathrm{~h}$; (vi) $200 \mu \mathrm{M} \mathrm{SA}, 2 \mathrm{~h}$; (vii) $200 \mu \mathrm{M} \mathrm{SA}, 8 \mathrm{~h}$. Total RNA was isolated, and differential display analysis was carried out as previously described (Horvath and Chua 1996) with the GenHunter RNAmap kit (GenHunter, Nashville, TN). ddPCR products of interest were amplified, purified from agarose gels, and used as probes for RNA gel analysis. PCR fragments were subcloned into the pT7-Blue vector (Novagen, Madison, WI) and sequenced with the Sequenase 2.0 kit (U.S. Biochemical, Cleveland, OH). Nucleotide and translated nucleotide sequences were com- pared against the nucleotide and protein sequences of the GenBank nonredundant data bases, as well as against the nucleotide and translated nucleotide sequences of the EST data bases, with the BLAST server (Altschul et al. 1990).

\section{RNA analysis.}

Total RNA was prepared from frozen tissue as previously described (Horvath and Chua 1996). Poly(A) mRNA was prepared by denaturing total RNA dissolved in $\mathrm{H}_{2} \mathrm{O}$ at $65^{\circ} \mathrm{C}$ for 15 min, adjusting to $0.5 \mathrm{MNaCl}$ in $\mathrm{TE}(10 \mathrm{mM}$ Tris/ $1 \mathrm{mM}$ EDTA, pH 8.0), and loading onto an oligo d(T) cellulose column equilibrated in $0.5 \mathrm{M} \mathrm{NaCl}$ in TE. The column was washed with 10 bed volumes of $0.5 \mathrm{M} \mathrm{NaCl}$ in $\mathrm{TE}$, and the eluant was passed over the column two times. The poly(A) mRNA was eluted with TE $\mathrm{pH}$ 8. RNA concentrations were determined spectrophotometrically, and either $20 \mu \mathrm{g}$ of total RNA or $1 \mu \mathrm{g}$ of poly(A) mRNA was electrophoresed on denaturing agarose gels and transferred to nylon membranes. RNA blots were hybridized with random-primed, ${ }^{32} \mathrm{P}$-labeled DNA probes (Megaprime kit, Amersham, Arlington, IL) at $55^{\circ} \mathrm{C}$, and visualized by autoradiography. Quantitation of RNA levels was accomplished by Phosphorimager analysis of radioactive membranes (Molecular Dynamics, Sunnyvale, CA). Levels of $\beta$-ATPase mRNA were used to normalize variation in signals due to loading differences between lanes.

\section{cDNA cloning.}

Full-length cDNA clones of the $C 18-1$ and $G 8-1$ ddPCR products were retrieved from a cDNA library prepared from cultured tobacco cells treated with $71 \mu \mathrm{M} \mathrm{CHX}$ and $200 \mu \mathrm{M}$ SA for $4 \mathrm{~h}$ (Horvath and Chua 1996) with labeled PCR fragments. Positive phage were isolated through three rounds of purification and subjected to in vivo excision to produce the pBluescript SK II plasmid clones.

\section{TMV inoculations.}

Seeds of Nicotiana tabacum cv. Xanthi, genotypes NN and $\mathrm{nn}$, were grown as previously described and maintained in growth chambers at $22^{\circ} \mathrm{C}$ with a $16 \mathrm{~h}$ light/ $8 \mathrm{~h}$ dark cycle (Horvath and Chua 1996). When plants were approximately 8 weeks old, the youngest fully expanded leaf was inoculated with $500 \mathrm{ng}$ of TMV (100 to 300 lesion forming units) in 50 $\mathrm{mM}$ phosphate buffer or mock-inoculated with phosphate buffer alone. Leaves were first dusted with Carborundum, wiped with the virus or buffer solution, and rinsed with $\mathrm{H}_{2} \mathrm{O}$. At sampling times, leaves were detached and immediately frozen in liquid nitrogen.

\section{ACKNOWLEDGMENTS}

D. M. H. thanks Curt Horvath and Ueli Klhare for critical reading of the manuscript. This work was supported by a grant from the Department of Energy to N.-H. C. (DOE94ER20143) and by a ZENECA, Ltd., Postdoctoral Fellowship (grant no. 247) to D. M. H.

\section{LITERATURE CITED}

Abel, S., and Theologis, A. 1996. Early gene and auxin action. Plant Physiol. 111:9-17.

Almendral, J. M., Sommer, D., MacDonald-Bravo, H., Burckhardt, J., Perera, J., and Bravo. R. 1988. Complexity of the early genetic response to growth factors in mouse fibroblasts. Mol. Cell. Biol. 8: 2140-2148. 
Altschul, S. F., Gish, W., Miller, W., Myers, E. W., and Lipman D. J. 1990. Basic local alignment search tool. J. Mol. Biol. 215:403-410.

Asselin, A., Grenier, J., and Cote, F. 1985. Light-influenced extracellular accumulation of $\mathrm{b}$ (pathogenesis-related) proteins in Nicotiana green tissue induced by various chemicals or prolonged floating on water. Can. J. Bot. 63:1276-1282.

Beadling, C., Johnson, K. W., and Smith, K. A. 1993. Isolation of interleukin 2-induced immediate-early genes. Proc. Natl. Acad. Sci. USA 90:2719-2723.

Bevan, M., Stiekema, W., Murphy, G., Wambutt, R., Pohl, T., Terryn, N., Kreis, M., Kavanagh, T., Entian, K. D., Rieger, M., James, R., Puigdomenech, P., Hatzopoulos, P., Obermaier, B., Duesterhoft, A., Jones, J., Palme, K., Ansorge, W., Delseny, M., Bancroft, I., Mewes, H. W., Schueller, C., and Chalwatzis, N. 1997. EU Arabidopsis sequencing project. NCBI. Online, data base ID gnl/PID/e327020.

Bi, Y.-M., Kenton, P., Mur, L., Darby, R., and Draper, J. 1995. Hydrogen peroxide does not function downstream of salicylic acid in the induction of PR protein expression. Plant J. 8:235-245.

Cao, H., Glazebrook, J., Clarke, J. D., Volko, S., and Dong, X. 1997. The Arabidopsis NPRI gene that controls systemic acquired resistance encodes a novel protein containing ankyrin repeats. Cell 88:57-63.

Cawley, K. C., Ramachandran, C., Gorin, F. A., and Walsh, D. A. 1988. Nucleotide sequence of cDNA encoding the catalytic subunit of phosphorylase kinase from rat soleus muscle. Nucleic Acids Res. 16:23552356.

Chen, Z., Silva, H., and Klessig, D. F. 1993. Active oxygen species in the induction of plant systemic acquired resistance by salicylic acid. Science 262:1883-1886.

Draper, J. 1997. Salicylate, superoxide synthesis and cell suicide in plant defence. Trends Plant Sci. 2:162-165.

Du, H., and Klessig, D. 1997. Identification of a soluble, high-affinity salicylic acid-binding protein in tobacco. Plant Physiol. 113:1319-1327.

Durner, J., Shah, J., and Klessig, D. F. 1997. Salicylic acid and disease resistance in plants. Trends Plant Sci. 2:266-274.

Eyal, Y., Sagee, O., and Fluhr, R. 1992. Dark-induced accumulation of a basic pathogenesis-related (PR-1) transcript and a light requirement for its induction by ethylene. Plant Mol. Biol. 19:589-599.

Hildmann, T., Ebneth, M., Pena-Cortes, H., Sanchez-Serrano, J. J., Willmitzer, L., and Prat, S. 1992. General roles of abscisic and jasmonic acids in gene activation as a result of mechanical wounding. Plant Cell 4:1157-1170.

Horvath, D. M., and Chua, N.-H. 1996. Identification of an immediateearly salicylic acid-inducible tobacco gene and characterization of induction by other compounds. Plant Mol. Biol. 31:1061-1072.

Jepson, I., Lay, V. J., Holt, D. C., Bright, S. W. J., and Greenland, A. J. 1994. Cloning and characterization of maize herbicide safenerinduced cDNAs encoding subunits of glutathione S-transferase isoforms I, II and IV. Plant Mol. Biol. 26:1855-1866.

Jupin, I., and Chua, N.-H. 1996. Activation of the CaMV as-1 ciselement by salicylic acid: Differential DNA-binding of a factor related to TGA1a. EMBO J. 15:5679-5689.

Kim, S.-R., Kim, Y., and An, G. 1993. Identification of methyl jasmonate and salicylic acid response elements from the nopaline synthase (nos) promoter. Plant Physiol. 103:97-103.

Larner, A. C., Chaudhuri, A., and Darnell, J. E., Jr. 1986. Transcriptional induction by interferon. J. Biol. Chem. 261:453-459.

Lau, L. F., and Nathans, D. 1987. Expression of a set of growth-related immediate-early genes in BALB/c 3T3 cells: Coordinate regulation with $c$-fos or $c$-myc. Proc. Natl. Acad. Sci. USA 84:1182-1186.

Lawton, K. A., Potter, S. L., Uknes, S., and Ryals, J. 1994. Acquired resistance signal transduction in Arabidopsis is ethylene independent. Plant Cell 6:581-588.

Liang, P., and Pardee, A. B. 1992. Differential display of eukaryotic messenger RNA by means of the polymerase chain reaction. Science 257:967-971.

Malamy, J., Carr, J. P., Klessig, D. F., and Raskin, I. 1990. Salicylic acid: A likely endogenous signal in the resistance response of tobacco to viral infection. Science 250:1002-1004.

Melan, M. A., Dong, X., Endara, M. E., Davis, K. R., Ausubel, F. M., and Peterman, T. K. 1993. An Arabidopsis thaliana lipoxygenase gene can be induced by pathogens, abscisic acid, and methyl jasmonate. Plant Physiol. 101:441-450.

Mhiri, C., Morel, J. B., Vernhattes, S., Casacuberta, J. M., Lucas, H., and Grandbastien, M. A. 1997. The promoter of the tobacco Tnt1 retro- transposon is induced by wounding and abiotic stress. Plant Mol. Biol. 33:257-266.

Moreau-Mhiri, C., Morel, J.-B., Audeon, C., Ferault, M., Grandbastien, M.-A., and Lucas, H. 1996. Regulation of expression of the tobacco Tnt1 retrotransposon in heterologous species following pathogen stress. Plant J. 9:409-419.

Neuenschwander, U., Vernooij, B., Friedrich, L., Uknes, S., Kessman, H., and Ryals, J. 1995. Is hydrogen peroxide a second messenger of salicylic acid in systemic acquired resistance? Plant J. 8:227-233.

Ohme-Takagi, M., and Shinshi, H. 1995. Ethylene-inducible DNA binding proteins that interact with an ethylene-responsive element. Plant Cell 7:173-182.

Qin, X. F., Holuigue, L., Horvath, D. M., and Chua, N.-H. 1994. Immediate-early induction of transcription by salicylic acid via the cauliflower mosaic virus as-1 element. Plant Cell 6:863-874.

Ryals, J., Weymann, K., Lawton, K., Friedrich, L., Ellis, D., Steiner, H.Y., Johnson, J., Delaney, T. P., Jesse, T., Vos, P., and Uknes. S. 1997. The Arabidopsis thaliana NIM1 protein shows homology to the mammalian transcription factor inhibitor IkB. Plant Cell 9:425-439.

Shah, J., Tsui, F., and Klessig, D. F. 1997. Characterization of a salicylic acid-insensitive mutant (sail) of Arabidopsis thaliana, identified in a selective screen utilizing the SA-inducible expression of the tms 2 gene. Mol. Plant-Microbe Interact. 10:69-78.

Strange, C., Ramirez, I., Gomez, I., Jordana, X., and Holuigue, L. 1997. Phosphorylation of nuclear proteins directs binding to salicylic acidresponsive elements. Plant J. 11:1315-1324.

Truesdale, M. R., Doherty, H. M., Loake, G. J., McPherson, M. J., Roberts, M. R., and Bowles, D. J. 1996. Molecular cloning of a novel wound-induced gene from tomato: twil. Plant Physiol. 112:446.

Uknes, S., Dincher, S., Friedrich, L., Negrotto, D., Williams, S., Thompson-Taylor, H., Potter, S., Ward, E., and Ryals, J. 1993. Regulation of pathogenesis-related protein-1a gene expression in tobacco. Plant Cell 5:159-169.

Ulmasov, T., Hagen, G., and Guilfoyle, T. 1994. The ocs element in the soybean GH2/4 promoter is activated by both active and inactive auxin and salicylic acid analogues. Plant Mol. Biol. 26:1055-1064.

Ward, E. R., Uknes, S. J., Williams, S. C., Dincher, S. S., Wiederhold, D. L., Alexander, D. C., Ahl-Goy, P., Métraux, J.-P., and Ryals, J. A 1991. Coordinate gene activity in response to agents that induce systemic acquired resistance. Plant Cell 3:1085-1094.

White, S. E., Habera, L. F., and Wessler, S. R. 1994. Retrotransposons in the flanking region of normal plant genes: A role for copia-like elements in the evolution of gene structure and expression. Proc. Natl. Acad. Sci. USA 91:11792-11796.

Xiang, C., Miao, Z.-H., and Lam, E. 1996. Coordinated activation of as1 -type elements and a tobacco glutathione $S$-transferase gene by auxins, salicylic acid, methyl jasmonate and hydrogen peroxide. Plant Mol. Biol. 32:415-426.

Xu, D., McElroy, D., Thornburg, R. W., and Wu, R. 1993. Systemic induction of a potato pin 2 promoter by wounding, methyl jasmonate, and abscisic acid in transgenic rice plants. Plant Mol. Biol. 22:573588

Yalpani, N., Balke, N. E., and Schulz, M. 1992. Induction of UDPglucose:salicylic acid glucosyltransferase in oat roots. Plant Physiol. 100:1114-1119.

Yalpani, N., Silverman, P., Wilson, T. M. A., Kleier, D. A., and Raskin, I. 1991. Salicylic acid is a systemic signal and an inducer of pathogenesis-related proteins in virus-infected tobacco. Plant Cell 3:809818

Yang, Y., and Klessig, D. F. 1996. Isolation and characterization of a tobacco mosaic virus-inducible $m y b$ oncogene homolog from tobacco. Proc. Natl. Acad. Sci. 93:14972-14977.

Zhang, B., and Singh, K. B. 1994. ocs element promoter sequences are activated by auxin and salicylic acid in Arabidopsis. Proc. Natl. Acad. Sci. USA 91:2507-2511.

Zhang, S., and Klessig, D. F. 1997. Salicylic acid activates a 48 kD MAP kinase in tobacco. Plant Cell 9:809-824

Zhou, J., Tang, X., and Martin, G. B. 1997. The Pto kinase conferring resistance to tomato bacterial speck disease interacts with proteins that bind a cis-element of pathogenesis-related genes. EMBO J. 16: 3207-3218.

Zipfel, P. F., Irving, S. G., Kelly, K., and Siebenlist, U. 1989. Complexity of the primary genetic response to mitogenic activation of human T cells. Mol. Cell Biol. 9:1041-1048. 